\title{
PENGOLAHAN IKAN DI DAERAH ALIRAN SUMBER AIR PANAS BUMI DI DESA PAYO KABUPATEN HALMAHERA BARAT PROVINSI MALUKU UTARA
}

\section{FISH DRYING IN HYDROTHERMAL WATER AT PAYO VILLAGE, WEST HALMAHERA, NORTH MALUKU PROVINCE}

\author{
Abdurrachman Baksir ${ }^{1}$,Nebuchadnezzar Akbar ${ }^{1 *}$, M. Yunus Hi Abbas ${ }^{2}$, Firdaut Ismail $^{1}$ \\ Irfan Haji ${ }^{1}$, Iswandi Wahab ${ }^{3}$ \\ ${ }^{1}$ Fakultas Perikanan dan Kelautan, Universitas Khairun, Ternate \\ ${ }^{2}$ Fakultas Teknik, Universitas Khairun Ternate \\ ${ }^{3}$ Fakultas Perikanan dan Ilmu Kelautan. Universitas Pasifik Morotai \\ *Korespondensi : nezzarnebuchad@yahoo.co.id
}

\begin{abstract}
Potential geothermal water is located on the coast of West Halmahera Regency. The geothermal potential is utilized by the community as a medium of traditional medicine and local tourism. Utilization of hot water sources as a fish processing media has not been done. The research objective was to determine the fish processing process by utilizing geothermal water sources by comparing the use of modified ovens without air holes and ovens with air holes at the bottom. The research material is anchovy (Stolephorus indicus) measuring $10 \mathrm{~cm}$. Fish drying equipment is made closed (airtight) as a whole. The process of fish maturation is done by laying the fish on the base located in the oven. Ovens that have holes have the opportunity to enter geothermal water from the bottom so that by delivering heat energy to water and steam on the walls of the oven, while ovens without holes only get influence from outside, the delivery of steam from hot water sources. The maturation process using the two oven media takes 2 hours, at an oven room temperature without a hole of $21^{\circ} \mathrm{C}$ with a geothermal water flow temperature of $49{ }^{\circ} \mathrm{C}-51^{\circ} \mathrm{C}$.
\end{abstract}

Keywords: Geothermal water, processing, oven, temperature

\section{Pendahuluan}

Wilayah Indonesia terletak di antara tiga lempeng bumi yang aktif, yaitu lempeng Pasifik, lempeng Indo-Australia dan lempeng Eurasia (Hutabarat dan Evans, 2006; Wibisono, 2011). Lempeng aktif artinya lempeng tersebut selalu bergerak dan saling berinteraksi. Lempeng Pasifik bergerak relatif ke Barat, lempeng Indo Australia relatif ke utara dan lempeng Eurasia bergerak relatif ke tenggara (Dahuri et al, 2008; Rompas et al, 2008). Aktivitas geothermal atau panas bumi merupakan potensi sumberdaya alam yang dapat dimanfaatkan dan dikembangkan. Terdapat 252 potensi geothermal yang tersebar di berbagai daerah Indonesia, dengan mengikuti jalur pegunungan vulkanik dan dimulai dari Jawa, Nusa Tenggara, Sulawesi dan Maluku (Suharmanto et al, 2015).

Maluku Utara sumber energi panas bumi yang dapat dimanfaatkan untuk dijadikan industri pengeringan sandang-pangan,listrik dan perikanan. Potensi panas bumi Maluku Utara adalah lapangan panas bumi di Jailolo, Kabupaten Halmahera Barat. Star Energy Geothermal (2014) melaporkan bahwa sumber panas bumi daerah tersebut memiliki enthalpy fluida sebesar $1100 \mathrm{~kJ} / \mathrm{kg}$ dengan suhu fluida minimum $179^{\circ} \mathrm{C}$. Baksir et al (2018) menemukan uap panas bumi meningkat 
seiring dengan peningkatan kedalaman galian, yakni $20 \mathrm{~cm}$ dengan nilai suhu 90 ${ }^{\circ} \mathrm{C}$ dan kedalaman $30 \mathrm{~cm}$ memiliki nilai $100{ }^{\circ} \mathrm{C}$. Potensi panas bumi tersebar disepanjang pesisir Jailolo Halamhera Barat. Desa Payo merupakan lokasi sumber panas bumi yang terletak di Kabupaten Halmahera Barat.

Potensi geothermal yang cukup besar ini belum dimanfaatkan secara optimal untuk dijadikan sebagai wadah yang dapat dimanfaatkan sebagai kawasan industri skala kecil. Masyarakat lokal memanfaatkan sumber air panas bumi ini sebagai lokasi wisata, meskipun kegiatan ini tidak memberikan manfaat ekonomi secara optimal. Hal ini dikarenakan minimnya wisatawan dari daerah luar yang masuk dan berkunjung. Lokasi air panas bumi ini lebih banyak dimanfaatkan masyarakat desa Payo untuk sekedar melakukan terapi.

Penelitian pemanfaatan panas bumi untuk pengolahan ikan di Desa Idamdehe Kabupaten Halmahera Barat telah dilaporkan Baksir et al (2018) yang menemukan pematangan ikan selama 30 menit pada suhu uap panas bumi $100{ }^{\circ} \mathrm{C}$, sedangkan metode konvensional diperoleh lama waktu pematangan yakni 1 jam pada suhu 100 ${ }^{\circ} \mathrm{C}$. Baksir et al (2019) menemukan proses pematangan ikan berlangsung selama 4 jam dengan suhu tercatat dalam ruang oven bernilai $0{ }^{\circ} \mathrm{C}, 50{ }^{\circ} \mathrm{C}$, dan $100{ }^{\circ} \mathrm{C}$.

Penelitian ini bertujuan untuk mengetahui proses pengolahan ikan dengan memanfaatkan sumber air panas bumi dengan membandingkan penggunaan oven modifikasi tanpa lubang udara dan oven dengan lubang udara pada bagian bawah.

\section{Metode Penelitian}

\section{Waktu, lokasi penelitian dan koleksi sampel}

Penelitian dilakukan bulan Juli-Agustus 2019 di daerah aliran sumber air panas bumi di Desa Payo, Kabupaten Halmahera Barat. Lokasi penelitian dapat dilihat pada Gambar 1. Penelitian ini menggunakan metode eksperimen lapangan (Kerlinger 1986; Ghazali et al. 2014 ; Baksir et al. 2018), yaitu dengan menggunakan alat pengeringan yang telah termodifikasi dengan menyesuaikan kondisi lingkungan. Peralatan pengeringan ikan dibuat tertutup (Kedap udara) secara keseluruhan (Gambar 2).

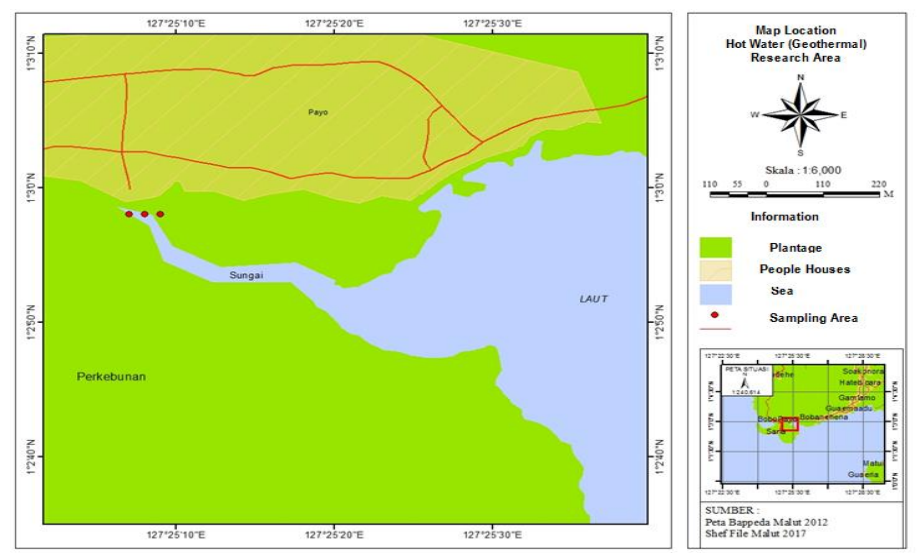

Gambar 1. Lokasi penelitian di desa Payo (Baksir et al, 2019)
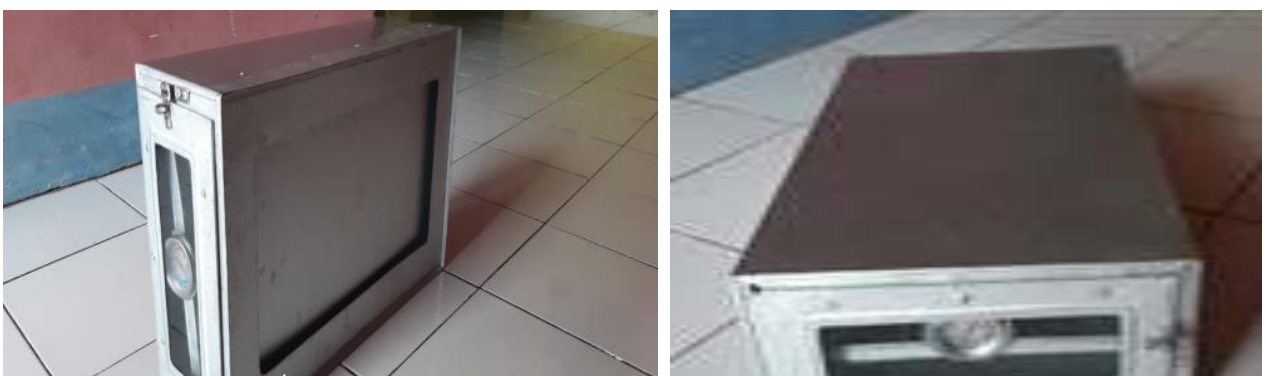
Gambar 2. Oven modifikasi memiliki lubang (A) dan tanpa lubang udara (B)

(Baksir et al. 2019)

Bahan penelitian yang digunakan yaitu ikan teri (Stolephorus indicus) berukuran $10 \mathrm{~cm}$ sampling dari pasar tradisional. Peralatan yang digunakan yaitu oven dengan kerangka ukuran tinggi $15 \mathrm{~cm}$, panjang $50 \mathrm{~cm}$, lebar $30 \mathrm{~cm}$ dan tinggi kaki $60 \mathrm{~cm}$, media peletakan oven dengan ukuran tinggi $75 \mathrm{~cm}$, panjang $52 \mathrm{~cm}$ dan lebar $32 \mathrm{~cm}$, capit ikan (panjang $35 \mathrm{~cm}$ ), wadah penyimpan (tupperware) berukuran $20 \times 15 \mathrm{~cm}$ dan sarung tangan. Oven diletakan diatas permukaan aliran air panas dengan kondisi terendam $3 \mathrm{~cm}$ meter dalam air.

\section{Prosedur penelitian}

Oven diletakan diatas permukaan aliran air panas dengan kondisi terendam 3 $\mathrm{cm}$ di dalam air. Oven yang diletakan tersebut terdiri dari oven tanpa lubang udara dan oven diberikan lubang udara yang telah didesain sebelumnya. Proses penempatan ikan dilakukan dengan membaringkan ikan pada bagian alas yang terletak dalam oven. Selanjutnya pengamatan ikan dilakukan setiap 1 jam sekali dengan total 8 jam setiap hari dan dilakukan pengulangan selama 6 hari.

Pengambilan data suhu ruangan menggunakan thermometer oven dengan akurasi nilai 0-300 ${ }^{0} \mathrm{C}$ yang diletakan dalam ruangan. Suhu lingkungan menggunakan thermometer digital dengan akurasi nilai $10-110{ }^{\circ} \mathrm{C}$.

\section{Analisis Data}

Analisis data berupa lama waktu pengeringan ikan uji yang dipakai Data yang diperoleh kemudian ditabulasi menggunakan Microsoft Excel dan dianalisis secara deskriptif, disajikan dalam bentuk grafik, diagram serta tabel.

\section{Hasil dan Pembahasan}

\section{Nilai temperature air panas dengan ruangan oven modifikasi}

Pengujian variabel temperature air panas bumi dan suhu ruangan oven diperoleh nilai yang berbeda. Pengambilan data kedua variabel dilakukan selama delapan jam. Pengamatan dilakukan pada satu kali dalam setiap jam. Data setiap jam penting dilakukan untuk memperoleh keakuratan informasi temperature air panas dan suhu ruangan. Selain itu dapat menggambarkan keadaan fluktuatif dari hasil pengujian. Hasil pengukuran oven modifikasi tanpa lubang memperlihatkan bahwa titik awal suhu air saat pengukuran $50,5^{\circ} \mathrm{C}$ (Gambar 3). Pergerakan suhu air panas bumi terjadi fluktuatif setiap jam dimana terdapat penurunan dan kenaikan suhu (Gambar 3). 


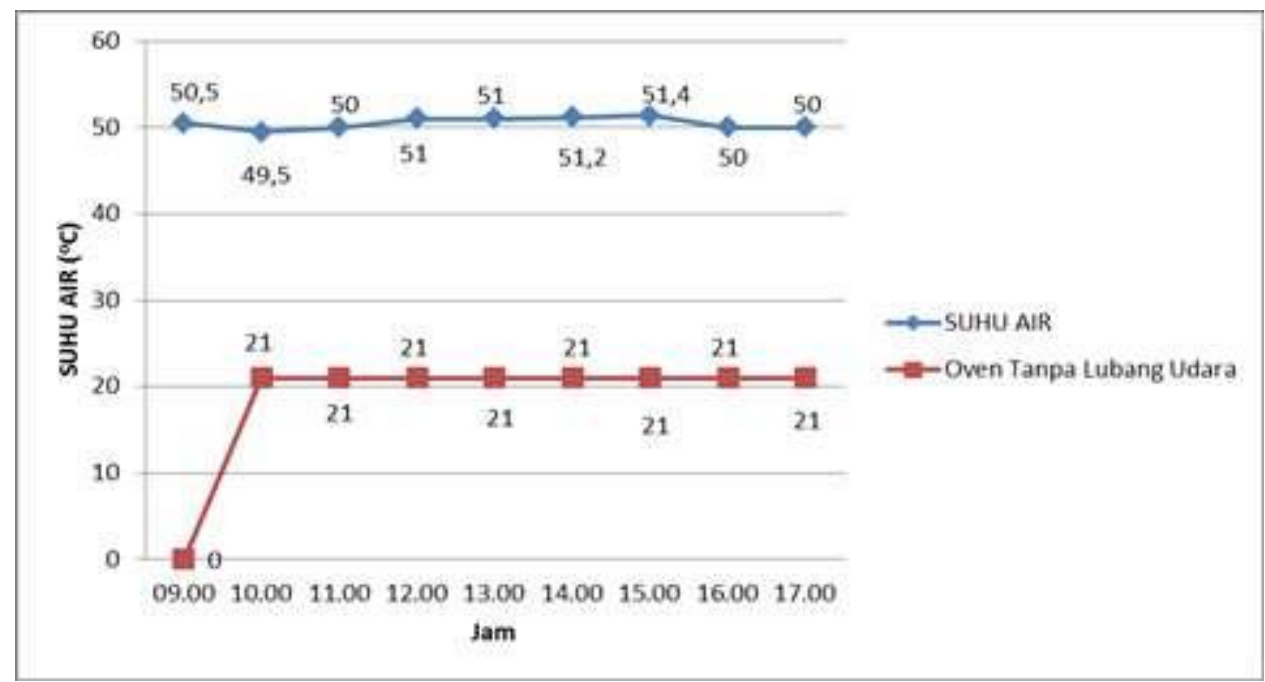

Gambar 3. Perbandingan temperatur air panas bumi dengan ruang oven modifikasi

Temperature ruang oven pada awal pengukuran bernilai $0{ }^{\circ} \mathrm{C}$, kemudian terjadi kenaikan $21{ }^{\circ} \mathrm{C}$ dalam rentang waktu dua jam (Gambar 3). Nilai suhu ruangan oven terlihat konstan pada saat pengukuran kedua yakni $21{ }^{\circ} \mathrm{C}$ selama delapan jam saat proses pematangan ikan dilakukan (Gambar 3). Suhu ruangan oven membutuhkan waktu selama dua jam untuk meningkatkan suhu ruangan. Yani et al (2009) mejelaskan bahwa efesiensi media dipengaruhi energi panas yang diterima oleh penyerap dan koefisien pindah panas pelat penyerap. Juliani dan Rahmatsyah (2016) Temperatur reservoir tergantung dari intensitas panas yang merambat dari batuan sumber panas, sifat termal batuan, seperti kemampuan batuan mengalirkan fluida (permeabilitas batuan). Temperatur reservoir tergantung dari intensitas panas yang merambat dari batuan sumber panas (Basid et al, 2014). Hal ini berbeda dengan pengukuran suhu lingkungan, dimana terjadi penurunan suhu saat pengukuran ke dua (Gambar 3). Suhu ruangan yang meningkat diduga diakibatkan aliran bahang panas dari air yang masuk kedalam ruang melalui dinding oven.

Oven yang terendam air panas dengan suhu tinggi serta waktu yang lama, dapat menghantarkan aliran panas kedalam ruangan oven. Keadaan fluktuatif pada suhu air panas bumi, kemungkinan dipengaruhi aliran air panas bumi dari titik sumber menuju ke permukaan berbeda-beda, keadaan cuaca dan proses penyinaran matahari. Nugroho dan Putra (2015) mengatakan bahwa panas yang keluar ini diakibatkan karena adanya celah atau retakan di kulit bumi. Selain itu juga teridentifikasi adanya retakan di sekitar sumber panas mata air sebagai media aliran air panas keluar ke permukaan (Rahmawati et al, 2017).

Hasil penelitian yang ditemukan juga dilaporkan Dieen dan Ulaan (2014), namun dengan objek yang berbeda yakni gabah. Hasil analisa menunjukkan presentase pengurangan kadar air gabah yang ideal pada posisi level air $15 \mathrm{~cm}$ yaitu sebesar 72,470 \% Penelitian berbeda dilakukan Tampubolon dan Pangabean (2019) yakni di Kecamatan Pahae Jae Kabupatan Tapanuli Utara, menemukan nilai suhu secara berurutan dan menunjukkan peningkatan suhu. Basid et al (2014) 
menemukan panas yang terdapat pada sumber mata air panas bukan dari aktivitas vulkanik, melainkan disebabkan oleh tatanan geologi daerah setempat (geopressured system) yang terasosiasi dengan zona depresi atau cekungan sedimen yang memanjang dari Jawa Barat dan Berpangkal di Jawa Timur sekitar ujung daerah madura. Laporan Ansar et al (2012) menunjukan perbedaan suhu pada ruang kolektor dan suhu lingkungan yang diukur pengukuran chips mangga.

\section{Pengolahan ikan pada aliran air panas bumi}

Pengeringan ikan dengan menggunakan oven modifikasi tanpa lubang air dilakukan selama selama 8 jam dengan perlakukan pengulangan tiga kali sehari. Hasil pengamatan pada proses pengeringan ikan dapat dilihat pada Gambar 4 dan Gambar 5.

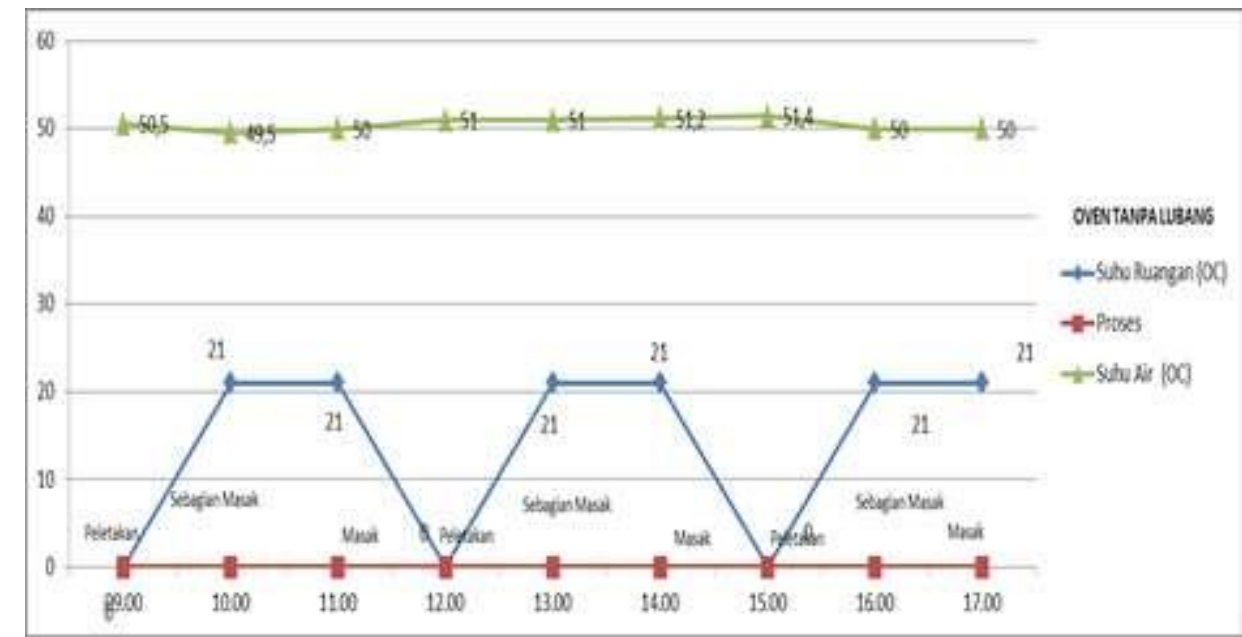

Gambar 4. Hasil pengolahan ikan dengan oven modifikasi tanpa lubang udara

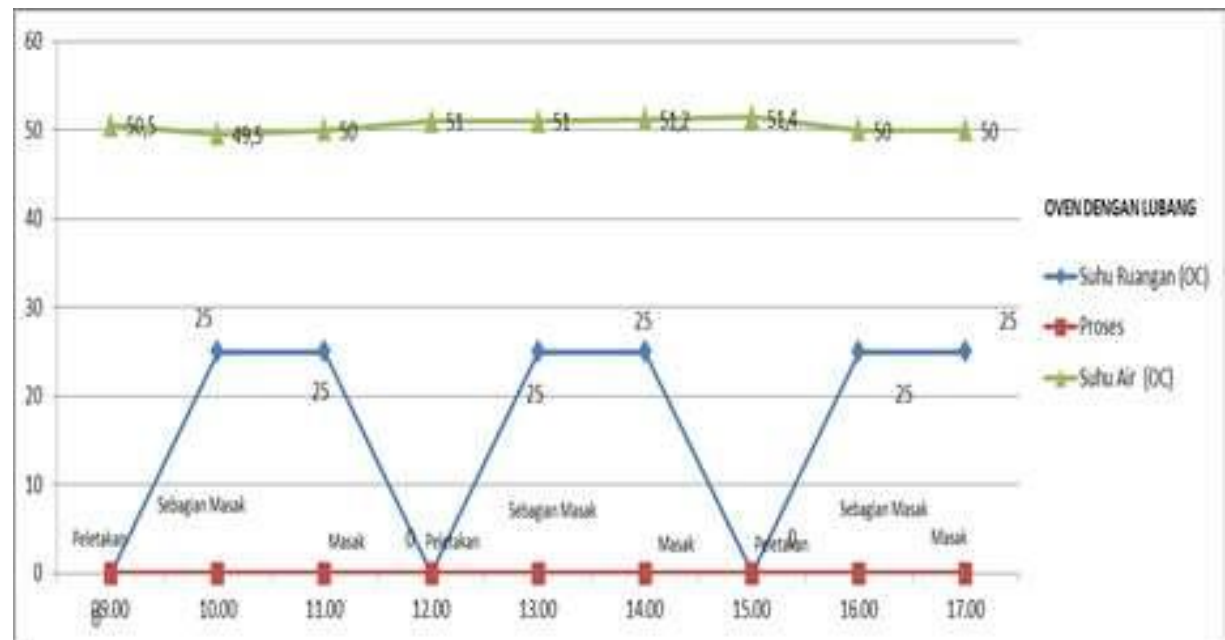

Gambar 5. Hasil pengolahan ikan pada oven modifikasi dengan lubang udara (Baksir et al.,2020)

Proses pematangan ikan pada pukul 09.00 hingga 17.00 WIT. Hasil pengeringan ditemukan bahwa ikan matang pada suhu ruangan $25^{\circ} \mathrm{C}$ dengan durasi waktu dua jam, pada suhu air panas bumi fluktuatif yakni antara $49{ }^{\circ} \mathrm{C}-51{ }^{\circ} \mathrm{C}$ 
(Gambar 4).Pengujian pertama pematangan ikan pada suhu ruang oven $0{ }^{\circ} \mathrm{C}$ saat titik awal peletakan dengan suhu air $50,5^{\circ} \mathrm{C}$, setelah itu bergerak naik $25^{\circ} \mathrm{C}$ pada pukul 10.00 WIT pada suhu air panas $49,5^{\circ} \mathrm{C}$ dengan status ikan setengah masak, kemudian pukul 11.00 WIT suhu ruangan oven tetap sama yakni $25^{\circ} \mathrm{C}$ pada suhu air panas bergerak naik menjadi $50{ }^{\circ} \mathrm{C}$ dengan kondisi ikan telah matang. Pengulangan kedua pukul 12.00 WIT saat ikan diletakan dengan suhu ruangan $0{ }^{\circ} \mathrm{C}$ pada suhu air $51^{\circ} \mathrm{C}$. Pengambilan data selanjutnya pada pukul 13.00 WIT dengan suhu ruangan yang telah naik yaitu $25{ }^{\circ} \mathrm{C}$ pada kondisi suhu air panas tetap $51{ }^{\circ} \mathrm{C}$ dan kondisi ikan setelah matang dan pukul 14.00 WIT status ikan masak dengan suhu ruangan $25^{\circ} \mathrm{C}$ pada. Pengulangan ketiga pematangan ikan pada pukul 15.00 WIT dengan suhu ruangan $0^{\circ} \mathrm{C}$ pada suhu air panas $51,4{ }^{\circ} \mathrm{C}$. Pengamatan kedua pukul 16.00 WIT dengan suhu ruangan naik $25^{\circ} \mathrm{C}$ pada suhu air panas yang bergerak turun $50^{\circ} \mathrm{C}$ dengan kondisi ikan setangah matang. Pengataman ketiga pukul 17.00 WIT dengan suhu ruangan konstan $25^{\circ} \mathrm{C}$ pada suhu air panas bumi yang sama $50{ }^{\circ} \mathrm{C}$ dengan status ikan matang. Suhu ruangan yang bergerak lambat dikarenakan bergantung pada daya hantar panas yang terdapat pada air panas bumi.

Tuyu et al (2011) mengatakan semakin lama waktu pengeringan, maka semakin banyak akndungan air yang keluar dari produk tersebut. Hal ini dapat dinyatakan bahwa lama pengeringan sangat mempengaruhi jumlah kadar air dalam produk. Pengeringan dengan cara seperti ini membutuhkan waktu yang cukup lama, dikarenakan media oven membutuhkan waktu untuk meingkatkan suhu ruangan melalui daya panas yang dialirkan sumber air panas bumi. selain itu air panas bumi memberikan pengaruh terhadap panas dinding oven. Proses pematangan ikan menggunakan oven tanpa lubang air memiliki kesamaan waktu proses pematangan menggunakan oven dengan lubang air yang di lakukan Baksir et al (2020). Proses pematangan dengan menggunakan dua media oven tersebut membutuhkan waktu dua jam, meskipun pada suhu ruangan yang berbeda. Suhu ruangan oven tanpa lubang air yakni $21^{\circ} \mathrm{C}$ sedangkan suhu ruangan oven dengan lubang air $25^{\circ} \mathrm{C}$ (Gambar 4 and 5).

Perbedaan suhu ruang oven diakibatkan pada oven dengan lubang memiliki peluang masuknya air panas bumi dari bagian bawah sehingga dengan mudah menghantarkan energi panas air dan uap pada dinding dan ruangan oven, sedangkan oven tanpa lubang air hanya mendapatkan pengaruh dari luar, melalui hantaran panas dan uap dari sumber air panas. Hatta et al (2019) mengatakan bahwa pengeringan suatu bahan, perpindahan bahan dari massa bahan ke udara berlangsung dalam bentuk uap atau terjadi pengeringan pada permukaan bahan. Namun demikian tidak mempengaruhi lama waktu pematangan ikan, sehingga dapat dikatakan bahwa ikan dapat matang pada kondisi suhu ruangan $21-25^{\circ} \mathrm{C}$ dengan kondisi suhu air panas $50{ }^{\circ} \mathrm{C}$.Namun demikian proses pematangan ikan yang dilakukan lebih cepat jika dibandingkan laporan Maulana (2010) dengan menggunakan energi bahan bakar untuk pembuatan ikan asin, dimana memburuhkan waktu 8 jam. Tuyu et al (2014) pada ikan asin yang dikeringkan 
dengan lama waktu 4-16 jam untuk mendapatkan kadar air yang rendah. Imbir et al (2015) melakukan pengeringan ikan layang asin dengan alat tenaga surya, dimana hasil menunjukan bahwa lama waktu pengeringan yaitu 8 jam. Firdaus (2016) melakukan perancangan dan analisa alat pengering ikan dengan memanfaatkan energi briket batubara, dimana hasil penelitian ditemukan tiga percobaan dengan lama waktu pengujian 1-3 jam.

\section{Kesimpulan}

Oven yang memiliki lubang mendapat peluang masuknya air panas bumi dari bagian bawah sehingga dengan cepat menghantarkan energi panas air dan uap pada dinding oven, sedangkan oven tanpa lubang hanya mendapat pengaruh dari luar, hantaran uap sumber air panas. Proses pematangan menggunakan kedua media oven tersebut membutuhkan waktu 2 jam, pada suhu ruang oven tanpa lubang 21 ${ }^{\circ} \mathrm{C}$ dengan suhu aliran air panas bumi $49{ }^{\circ} \mathrm{C}-51{ }^{\circ} \mathrm{C}$.

\section{Ucapan Terimakasih}

Penulis sampaikan terimakasih kepada Lembaga Penelitian dan Pengadian Kepada Masyarakat, Universitas Khairun (LPPM) yang telah memberikan dana melalui program Penelitian Kompetitif Unggulan Perguruan Tinggi (PKUPT) tahun anggaran 2019 dan pemerintah desa Payo, yang telah memberikan ijin selama penelitian berlangsung.

\section{Daftar Pustaka}

Baksir A, Daud K, Wibowo E.S, Akbar N, Haji I. 2018. Pengolahan ikan menggunakan sumber panas bumi di desa Idamdehe Kabupaten Halmahera Barat Provinsi Maluku Utara. Jurnal Pengolahan Hasil Perikanan Indonesia, $21(3)$ : 547-553

Baksir A, Daud K, Wibowo E.S, Akbar N, Haji I. 2019. Pemanfaatan sumber energi panas bumi untuk pengeringan ikan di desa Idamdehe Kabupaten Halmahera Barat Provinsi Maluku Utara. Jurnal Pengolahan Hasil Perikanan Indonesia, $22(3): 417-426$

Baksir A, Abbas M.Y.H, Akbar N, Ismail F, Haji I. 2020.Pengolahan Ikan Menggunakan Sumber Air Panas Bumi Di Desa Payo Kabupaten Halmahera Barat Provinsi Maluku Utara. Laporan Penelitian. Tidak Terpublikasi. Universitas Khairun.

Basid A, Andrini N, Arfiyaningsih S. 2014. Pendugaan reservoir sistem panas bumi dengan menggunakan survey geolistrik, resistivitas dan self potensial. Jurnal Neutrino, 7 (1) : 57-70

Dahuri R, Rais J, Ginting S.P, Sitepu M.J. 2008. Pengelolaan sumberdaya pesisir dan lautan secara terpadu. PT. Pratnya Paramita, Jakarta. hlm 328

Dien R.R, Ulaan T.V.V. 2014. Analisis potensi air panas di bukit kasih kanonang untuk pengering gabah. Jurnal Online Poros Teknik Mesin, 3 (2) : 78-89

Ghazali R.R, Swastawati F, Romadhon . 2014. Analisa tingkat keamanan ikan manyung (Arius Thalassinus) asap yang diolah dengan metode pengasapan berbeda. Jurnal Pengolahan dan Bioteknologi Hasil Perikanan, 3 (4) : 31-38. 
Hatta M, Syuhada A, Fuadi Z. 2019. Sistim pengeringan ikan dengan metode hybrid. Jurnal Polimesin, 17 (1) : 9-18

Hutabara S, Evans S.M. 2006. Pengantar oseanografi. UI Press, Jakarta. hlm 159

Imbir E, Onibala N, Pongoh J. 2015. Studi pengeringan ikan Layang (Decapterus $s p$ ) asisn dengan penggunaanalat pengeringan surya. Jurnal Media Teknologi Hasil Perikanan, 3(3):13-18.

Firdaus A. 2016. Perancangan dan analisa alat pengering ikan dengan memanfaatkan energi briket batubara. Jurnal Teknik Mesin, 5 (4) ; 128-136

Juliani R, Rahmatsyah. 2016. Pola kandungan mineral dan potensi panas bumi Siogung-Ogung Kabupaten Samosir. Jurnal Generasi Kampus, 9 (2) : 277288

Kerlinger, F. 1986. Foundations of behavioral research (2nd edition). holt, rinehart and winston.

Maulana M.I. 2010. Penggunaan energi bahan bakar untuk pengeringan ikan asin/keumamah. Mekanika, 8 (2) : 178-182

Nugroho E.B, Putra A. 2015. Estimasi temperatur reservoir panas bumi berdasarkan resistivitas listrik teras silika di sekitar mata air panas Kecamatan Alam Pauh Duo, Kabupaten Solok Selatan. Jurnal Fisika Unand, 4 (4) : 339-343

Rahmawati, Maryanto S, Susilo A . 2017. Identifikasi sistem panas bumi daerah Cangar, Jawa Timur menggunakan metode magnetotelurik. Journal of Physical Science and Engineering, 2 (2) : 72- 82

Rompas R.M, Hutabarat S, Rompas J.R. 2008. Pengantar ilmu kelautan. Cetakan kedua. sekretaris dewan kelautan Indonesia. hlm 150

Suharmanto P., A.N. Fitria., S. Ghaliyah. 2015. Indonesian geothermal energy potential as source of alternative energy power plant. KnE Energy. 1 : 119124.

Tampubolon T, Panggabean Y. 2016. Identifikasi permukaan daerah geothermal PLTP sarulla unit menggunakan citra satelit di Kecamatan Pahae Jae Kabupatan Tapanuli Utara. Jurnal Einstein, 7 (1) : 26-31.

Tuyu A, Onibala H, Makapedua D.M. 2014. Studi lama pengeringan ikan Selar (Selaroides sp) asin dihubungkan dengan kadar air dan nilai organoleptik. Jurnal Media Teknologi Hasil Perikanan, 2 (2) ; 20-26

Wibisono M.S. 2011. Pengantar Ilmu Kelautan. UI Press. Jakarta. hlm 253

Yani E, Abdurrachim,Pratoto A. 2009. Perhitungan efisiensi kolektor surya pada pengering surya tipe aktif tidak langsung. Jurnal Teknik, 31: 26-33. 